\title{
The Making of Intellectual Women
}

\author{
Review essay by Valentina Mitkova
}

Boiko Penchev, Nikolay Papuchiev, Noemi Stoichkova, Bilyana Borisova, Kristina Iordanova, Nadezhda Stoyanova, and Sirma Danova, eds., Literaturata: Udovolstvia i predizvikatelstva. Jubileen sbornik $v$ chest na prof. Milena Kirova (The literature: Pleasures and challenges. Anniversary collection in honor of Prof. Milena Kirova), Sofia: University Press St. Kliment Ohridski, 2018, 728 pp., BGN 26 (hardback), ISBN: 978-954-074-573-2.

Kamelia Spasova, Darin Tenev, and Maria Kalinova, eds., Parachoveshkoto: Gracia i gravitacia. Jubileen sbornik $v$ chest na prof. Miglena Nikolchina (The parahuman: Grace and gravity. Anniversary collection in honor of Prof. Miglena Nikolchina), Sofia: University Press St. Kliment Ohridski, 2017, 976 pp., BGN 30 (hardback), ISBN: 978-954-07-4268-7.

Lyudmila Malinova, Kristina Iordanova, and Marineli Dimitrova, eds., Zhenite v bulgarskata literatura $i$ kultura (The women in Bulgarian literature and culture), Sofia: University Press St. Kliment Ohridski, 2018, 526 pp., BGN 22 (paperback), ISBN: 978-954-07-4363-9.

In recent years, in a changed (postsocialist and polyphonic) political and sociocultural environment, humanities in the Bulgarian context have registered a highly productive and authoritative female participation and expertise. Decisively crossing disciplinary and methodological boundaries, incorporating the analytical optics of deconstruction and postmodernism, Bulgarian women researchers in the fields of literature and literary historiography and social and cultural history have successfully mobilized a wide range of problems, drew new research trajectories, and rethought the cultural tradition and intellectual continuity among generations. While problematizing the legacy of the androcentric regimes and popular notions of canonicity in the field of cultural production, they have focused their efforts on bringing women out of the sphere of marginality where they have been traditionally positioned and validating their contributions to the writing of modern Bulgarian history. The three books referenced in this article embody similar examples of women's productivity and diversity in the field of intellectual activities, highlighting the multifaceted efforts of some of the leading women researchers in contemporary Bulgarian humanities. 
Literaturata: Udovolstvia i predizvikatelstva (Literature: Pleasures and challenges) is an anniversary collection in honor of one of the most prominent figures in Bulgarian literary criticism, history, and literary studies in the last twenty years, Milena Kirova. By generating an intellectual forum for literary historians and researchers from various academic institutions, the book collects texts thematically targeting the central fields in which Kirova works. It is precisely the various analytical directions that she introduced and developed in her professional activity that determine the different sections of the volume.

The first part of the book, "Arheologia na bibleiskia text" (The archaeology of the biblical text), demonstrates Kirova's involvement in the methodological approaches and strategies of various humanitarian fields (anthropology, psychology, literary studies, and feminist studies) in the field of biblical exegesis, as well as her contribution to modern efforts in analytical reading of sacred texts. Within this context, one of the central topics that Kirova has dealt with is the way in which the biblical notions of femininity and masculinity are constructed. ${ }^{1}$ The latter are interpreted as keys to reading the established patterns of mentality and gender stereotypes with which the patriarchal world operates (the biblical text is understood as a matrix of patriarchal thinking and the basis of the binary oppositions through which the latter "sees" the world). Within this context, the texts "Filologicheska arheologia na bibleiskata muzhestvenost" (A philological archaeology of Biblical masculinity) by Ivan Stankov; "Licata na razpolovenia chovek v izsledvaneto na sociopola v Evreiskata biblia ot Milena Kirova" (The faces of a person's gendered partitioning in Milena Kirova's research on gender in the Hebrew Bible) by Julia Yordanova-Pancheva; "From Feminine to Masculine in Biblical Texts: The Contribution to Milena Kirova" by Roland Boer; and others correspond to Kirova's interests or function as tributes to her work.

The second part of the collection, "Antropologia v novi nasoki" (Anthropology in new directions), references Kirova's research focus on mythological thinking. ${ }^{2}$ Similarly to her work, the purpose of the articles included is to highlight and analyze the importance (and translation) of certain sociomythological and archetypal constructions, folklore imagery, and stylistics in the mental entities of literature, art, and contemporary popular culture.

This section is rather laconic, represented by three texts only, but the third part of the book, "Ah, this gender!" (All that gender!), is among the most extensive, corresponding to one of the most substantial areas in Milena Kirova's research. ${ }^{3}$ The deep interest in gender-related issues or the topic of the social construction of gender consciousness (the difference between sex as a biological assumption and gender as an identity acquired and affirmed in the process of socialization, in accordance with certain concepts of femininity and masculinity) locates Kirova's studies in dialogue with contemporary perspectives and achievements in the field of women's and gender history. It is in this (interdisciplinary) paradigm that texts such as "Za genezisa na edno poniatie" (On the genesis of a concept) by Maya Razboinikova-Frateva; "V muzhkia klub': Zhenskoto uchastie v Sujuza na bulgarskite pisateli (1913-40-te godini na XX v.)" (In the gentlemen's club: Women's participation in the Union of Bulgarian Writers [1913-1940s]) by Georgeta Nazarska; “Dve lica na zhenstvenostta v suvremennata bulgarska proza" (Two faces of femininity in contemporary Bulgarian prose) by Kris- 
tina Yordanova; "Chetene i emancipaci: Prevodnata feministka knizhnina v Bulgaria, XIX-nachaloto na XX vek" (Reading and emancipation: Translated feminist works in Bulgaria, the nineteenth century-beginning of the twentieth century) by Krassimira Daskalova; and others operate. By mobilizing various research strategies and focusing on different historical periods, the articles position gender problematics within the Bulgarian context in order to undertake different tasks: to trace the historical roots of the theoretical division between sex and gender and its commitment to the political movements for equality between men and women; to outline the links between literacy, translation, reading, and the emancipation of women in Bulgaria at the turn of the twentieth century; to examine women's empowerment in the artistic associations in the country and their place among the so-called reputational male elites in the first half of the twentieth century; to study the way in which the concept of femininity operates in contemporary Bulgarian prose; and so forth.

The task of "Literaturnata istoria-pripiski kum kanona" (Literary history: Amendments to the canon), the fourth part of the collection, is to discuss, from different angles and in terms of different historical periods, what is known as the Bulgarian literary heritage. Starting from the period of the so-called Bulgarian national revival and ending with post-1989 literature, the texts collected in this section focus on various problems (the treatment of death in Bulgarian prose after the establishment of the Bulgarian nation-state, marionettes and social masks in Bulgarian literature of the 1920s, the elaboration of spatial imaginary in the literary discourse of the 1960s, etc.) and literary-mostly male but also some female-figures (Hristo Botev, Rayko Zhinzifov, Lora Karavelova, Stefan Gechev), while crossing diverse literary languages (the revolutionary language of the late national revival period, the expressiveness of symbolic poetry, the vocabulary of diabolical prose, etc.). The multiple directions of research offered by the articles refer to fields in literature that remain unexplored or possess extensive interpretative potential. They also point to the reductive nature of the literary canon, suggesting alternative versions of literary narratives-a topic to which Milena Kirova has devoted a significant part of her professional activity. ${ }^{4}$

Unlike the previous parts of the book, the focus of the fifth section, entitled "Literaturnata kritika: Suvremenni predizvikatelstva" (Literary criticism: Contemporary challenges), is different-its focus falls on the aspirations and tendencies typical of contemporary Bulgarian literature. The optics of the texts included in this section are directed at migrant memoir prose, the nature of the fuga-novels, and perspectives on translated Bulgarian literature. Articles that emphasize the merits and transgressions of serious criticism, as well as the role of literary critics in the development of valuable literature, are also included-an emphasis that directly refers to the professional mission of Milena Kirova.

The closing part of the volume, "Puteki na globalizaciata: Literaturata i literaturnata nauka po sveta" (Avenues towards globalization: Literature and literary studies around the world), is the next step in enlarging the picture that the book presents to its readers. The section corresponds to its title by going beyond local themes. By crossing national borders and cultural contexts it focuses on authors from the world literary scene and meets various theoretical and literary-historical models of artistic reception (techniques that are certainly representative of Kirova's writing). 
Similar to the compositional architecture and concept of Literaturata: Udovolstvia $i$ predizvikatelstva is the second book under review here, also honoring women's contributions to the intellectual realm. Parachoveshkoto: Gracia i gravitacia (The parahuman: Grace and gravity) is an anniversary collection dedicated to Miglena Nikolchina, a Bulgarian author of poetry and prose, a literary historian, and a theoretician whose research interests mobilize the interaction of different disciplinary fields-literature, philosophy, political science, feminism-generating new guidelines and perspectives in the sphere of humanities.

The task of the book, which brings together texts by Bulgarian and foreign researchers, is to follow the threads of Nikolchina's creative pursuits and academic interests, to reproduce the multilayered fabric of her intellectual contributions. The first part of the volume, entitled "Chovek, zhivotno, mashina" (Man, animal, machine) is a replica of some of the key themes in Nikolchina's work. Centered on the problem of human boundaries (framed by certain forms of the nonhuman in the face of the angel, the animal, the puppet, God, the machine, the automaton), as well as its transformations, the texts included in this section discuss issues such as the cognitive value of the juxtaposition between video games and literature in terms of narrative theory, the exquisite communication with computers and their invasion in human spaces of thought, the philosophical category of the "human animal" and the opportunities for distinction of humans, anti-humanism, and others.

"Chovek, zhivotno, mashina" enters into a dialogue with the third part of the collection, "Chovekut-utopia" (The utopia-man). The latter raises the question of shifting the utopian imagination to projects for the enhancement and transformation of the human being, focusing on the topic of transhumanism-an area whose ethical parameters are among Nikolchina's key interests. ${ }^{5}$ The presence of the topic of heterotopy, ${ }^{6}$ on the other hand, builds a bridge between the third section and the second part in the volume. Crossing theoretical and biographical issues, the second part of the book, entitled "Seminarut" (The seminar), references Nicolchina's research on the geo-cultural differences between the dreams and ideas of Eastern intellectuals of the 1980s (shared in the form of seminary utopia) and Western academic and intellectual realities. ${ }^{7}$ This interest is shared by texts such as "Melanholichiat efekt na heterotopiite" (The melancholic effect of heterotopias) by Andrey Bundjulov; "Istoria na glasove i otgovornosti" (The authentic story, their voices and responsibility) by Dobromir Grigorov; "Spomen za 90-te, ili pogled kum literaturata otkum mediate" (Remembering the 1990s, or a media perspective on literary criticism) by Marin Bodakov; and so on.

Unlike "Seminarut," which is aimed at the theoretical and philosophical contributions of Nikolchina, the section "Gradut na Amazonkite" (The city of Amazons) turns to her poetic creativity, focusing on its expressive means and thematic circles: the article "Poeziata na Miglena Nikolchina: Tuga i vuzvisiavane" (The poetry of Miglena Nikolchina: Sorrow and exaltation) by Amelia Licheva, for example, is an attempt at reading the works of the poetess through the prism of a story about revolt and irreconcilability, sorrow and exaltation; the text "Po rubovete na sebe si" (On the edges of the self) by Nadezhda Radulova explores the self-edging strategies in Miglena Nikolchina's poetry, which dwell on the idea of the fantastic; "Asketichnoto $u$ Miglena Nikolchina" (Ascetism in Miglena Nikochina's work) by Maurice N. Fadel 
aims at a marginal feature in the overall artistic concept of the poetess, "asceticism" (understood as a road to alternative versions of life). These are only a few of the ways of illustrating the multilayered texture of her poetry.

"Asimvolia" (Asymbolia)—the fifth thematic part of the volume-outlines Miglena Nikolchina's interests in the field of Western European literature and modernism, interpreted through the theoretical optics of Julia Kristeva. ${ }^{8}$ The feminist line continues in "Bialo vurhu bialo" (White on white) - the sixth section of the book-but is transferred to the Bulgarian context. The texts included there contribute to the exploration of the possibility of a female literary tradition, examine key thematic fields of women's writing in a historical context, and focus on the problematic nature of contemporary projects of an alternative (female) literary canon.

"Devi, ricari, kralici" (Virgins, knights, queens), in turn, runs through time and space, bringing together texts that communicate with Nicolchina's research exploring ancient Greek, medieval, Renaissance, and romantic literature. ${ }^{9}$ Unlike the previous seven, the eighth and final part of the collection, "Estetika i suprotiva" (Aesthetics and resistance), includes texts that focus (through the lens of politics, history, ethics, and aesthetics) on the personal genealogies of authors and intellectuals forced to work in the context of different ideological regimes: the Soviet dissident writers Andrei Siniavski and Julii Daniel; the Bulgarian author, literary critic, translator, and philosopher Tzvetan Stoyanov (whose creative and political stance aimed at intellectual opposition to the communist regime falls within the research focus of Nikolchina herself ${ }^{10}$ ); the authors Georgi Markov and Pavel Vezhinov, and so forth.

Both collections discussed so far end with impressive bibliographies, which list the works of the two jubilees, thus illustrating the multiple thematic and genre layers that characterize their writing. Personal genealogy is also mobilized but does not exhaust the research strategies applied in the third book under review here on women's presence in the field of intellectual and artistic activities. The collection Zhenite $v$ bulgarskata literatura i kultura (Women in Bulgarian literature and culture), the result of an interdisciplinary conference with the same name held at Sofia University "St. Kliment Ohridski" in 2016, brings together studies related to the history of women in various fields of society, culture, and arts. Articulating the efforts of researchers from different universities, cultural institutions, and professional units, the volume traces women's contributions - social, political, professional, and creative-in a broad historical perspective (from the period of the nineteenth-century Bulgarian national revival to the present), thus demonstrating the diversity of the field of women's and gender history in the Bulgarian context.

Without following a deliberate compositional structure, the book is a crossing point of texts that oscillate between general concepts and particular cases within the overall thematic frame. Several of the selections are of a theoretical character, discussing some of the leading interests of contemporary Bulgarian feminist researchers. Such are the articles "Patriarhalno i politichesko: Kum zhenskia vupros mezhdu dvete svetovni voini" (Patriarchal and political: A contribution on the "woman question" in the interwar period) by Kristina Yordanova, which pays attention to women's situation as one of the popular topics in Bulgarian public discourse between World War I and World War II; "Zhenski dvizhenia i feminimi i proizvodstvoto na znanie za vtorata polovina 
na XX vek" (Women's movements and feminisms, and the production of knowledge during the second half of the twentieth century) by Krassimira Daskalova, which looks at the complex and contested theme of women's activism in Eastern Europe during the Cold War period; "Seksut i vlastta: Pogled kum 1968-a i otvud" (Sex and power: A look at 1968 and beyond) by Albena Vacheva, which focuses on the marginalization of gender and sexuality issues within public discourse during state socialism in Bulgaria; Kornelia Slavova's "Za bulgarskia feminizum v/kato prevod" (On Bulgarian feminism in/as translation), which examines the particular way in which Western feminist ideas and models made their way into Eastern European societies (and in the Bulgarian context too) in the early 1990s through "transmission" or "translation" of concepts into the plan for the overall democratization of postcommunist societies; and more.

Another part of the collection contains articles focusing on women of letters (authors of prose, poetry, memoirs), as well as musicians and artists, well-known or rarely falling within the reach of public attention, who have left a mark on Bulgarian cultural history (Ekaterina Vassileva, Clara Tsilka, Rada Kazaliyska, Irina Bachokirova, Mara Belcheva, Zhana Nikolova-Galabova, Vera Mutafchieva, Blaga Dimitrova, Ana Boyanova, Margarita Mladenova, Nevena Karamalakova, etc.). The texts "read" their life trajectories from different angles-tracing their biographies, highlighting unknown facts and forgotten episodes, exploring individual artistic profiles, registering examples of innovation, commenting on the public and critical reception of their works, and striving to popularize examples of authentic women's presence in the intellectual life of the country within different cultural and historical periods.

A third category of articles applies a macro lens to particular cases of literary women, analyzing leading themes in their works, the specifics of their artistic imagery, and certain genre biases. A similar scope is applied to specific phenomena in Bulgarian cultural and literary life, conceived as significant in terms of women's intellectual, professional, and social activity, as demonstrating women's solidarity or illustrating women's striving for creative and personal fulfillment and development.

Crossing various research perspectives that oscillate between past and present, general conclusions, and particular case studies, the purpose of the three collections is not just to inventory but also to value the efforts of Bulgarian women in the field of cultural and intellectual production, to make them visible and recognizable not just within the specialized fields of feminist research, but for the wider audience as well. Another function of the articles included in these three books is to demonstrate the ability of women occupied with intellectual activities and contributing to the sphere of humanities in particular to open up new discursive fields, to draw analytical trajectories, and to stimulate interdisciplinary dialogue as a tool for the multiplication of knowledge.

\section{$\diamond$ About the Author}

Valentina Mitkova is Assistant Professor in the history of the book and reading at Sofia University St. Kliment Ohridski. She is an author of book reviews and critical materials for Aspasia, as well as articles (both in English and Bulgarian) focused on Bulgarian women writers and intellectuals. E-mail: valentina.mitkova@abv.bg 


\section{$\diamond$ Notes}

1. Milena Kirova, Bibleiskata zhena: Mehanizmi na konstruirane, politiki na izobraziavane v Staria zavet [The biblical woman: Design mechanisms, politics of pepresentation]. (Sofia: Stigmati; University Press St. Kliment Ohridski, 2005); David Velikia: Istoria i muzhestvenost v evreiskata Biblia [David the Great: History and masculinity in the Hebrew Bible] (Sofia: Ciela, 2011).

2. Milena Kirova, "Samodivata i ogledaloto: Dva modela na identifikacia na zhenata v bulgarskia folklor" [The lioness and the mirror: Two models of women's identification in Bulgarian folklore], Literaturna misul [Literary thought], no. 3 (1933): 55-64; “Praktiki na mitologichnoto v literaturnia text (nie-identifikaciata i nie-identichnosti v tvorchestvoto na N. Vapcarov)" [Practices of the mythological in the literary text (We-identification and we-identities in the works of N. Vaptsarov)], in Anarhistut-zakonodatel: Jubileen sbornik v chest na prof. Nikola Georgiev [The anarchist-legislator: A collection dedicated to the jubilee of Prof. Nikola Georgiev], ed. Radosvet Kolarov (Sofia: 1999), 339-348.

3. Milena Kirova "Psihoanalizata pishe roda" [Psychoanalysis writes gender], in Teoria prez granicite: Vuvedenie $v$ izsledvaniata na roda [Theory across borders: Introduction to gender studies], ed. Milena Kirova and Kornelia Slavova (Sofia: Polis Publishers, 2001) 149-166; "Gender Identities in Transition: The Role of the Popular Culture and the Media in Bulgaria after 1989" (coauthored with Kornelia Slavova), in Gendering Post-Socialist Transition: Studies of Changing Gender Perspectives, ed. Krassimira Daskalova et al. (Vienna: LIT Verlag, 2011).

4. Milena Kirova, Literaturniat kanon: Predizvikatelstva [Literary canon: Challenges] (Sofia: University Press St. Kliment Ohridski, 2007]; Neslucheniat kanon: Bulgarskite pistelki ot Vuzrazhdaneto do Vtorata svetovna voina [The canon that did not happen: Bulgarian women writers from the national revival to World War II] (Sofia: Altera, 2009); Neslucheniat kanon: Bulgarskite pistelki ot 1944 godina do nashi dni [The canon that did not happen: Bulgarian women writers from 1944 to today] (Sofia: Altera, 2013).

5. Miglena Nikolchina "Geroiat-utopia" [The utopia-hero], Literaturna misul [Literary thought], no. 6 (1982): 103-116; Chovekut-utopia [The utopia-man] (Sofia: University Press St. Kliment Ohridski, 1992).

6. Heterotopia is a concept elaborated by the philosopher Michel Foucault to describe certain cultural, institutional, and discursive spaces that are somehow "other": disturbing, intense, incompatible, contradictory, or transforming. Heterotopias are worlds within worlds, mirroring and yet upsetting what is outside [Michel Foucault, The Order of Things (New York: Vintage Books, 1971)]. The West functions as a heterotopia in M. Nikolchina's works: it is a mirrormachine used for returning dreams to the place where they came from, accompanied by their normalization: that is, it is a mechanism for the capitalist destruction of utopian Eastern horizons.

7. Miglena Nikolchina, Izgubenite ednorozi na revoljuciata: Bulgarskite intelectualci prez 1980te $i$ 1990te godini [The lost unicorns of the revolution: Bulgarian intellectuals in the 1980s and 1990s] (Sofia: Literaturen vestnik, 2012).

8. Miglena Nikolchina, Matricide in Language: Writing Theory in Kristeva and Woolf (New York: Other Press, 2004).

9. Miglena Nikolchina, Devi, ritsari, kralici: Ljubovta v literaturata na Srednovekovieto $i$ Renesansa [Virgins, knights, queens: Love in the literature of the Middle Ages and the Renaissance] (Plovdiv: Zhanet 45, 2014).

10. Miglena Nikolchina, "Prochitut na komunisticheskoto nasledstvo prez nesuvpadashtoto suvpadenie: Tsvetan Stoyanov s Julia Kirsteva i Georgi Markov" [Reading the communist legacy through noncoinciding coincidences: Tzvetan Stoyanov with Julia Kristeva and Georgi Markov], Sociologicheski problemi [Issues of sociology], nos. 1-2 (2015): 154-170. 